\title{
Research on Human Resource Management of Small and Medium Sized Enterprises in the Perspective of Cross Culture
}

\author{
Minkuo Zhang \\ Hunan International Business Vocational College, Changsha Hunan, 410200, China
}

\begin{abstract}
Keywords: Cross culture perspective, Small and medium-sized enterprises, Human resource management.
\end{abstract}

\begin{abstract}
Human resource management of small and medium sized enterprises under the perspective of cross culture has become an important factor that affects the international development of small and medium sized enterprises. This article starts with the definition of cross culture human resource management, and puts forward the measures to strengthen human resource management of small and medium-sized enterprises based on cross culture perspective according to the development status of small and medium sized enterprises under the cross culture studies and problems in human resource management, hoping to provide the appropriate support and reference for the international development of small and medium-sized enterprises.
\end{abstract}

\section{Introduction}

After entering the new century, as the culture environment in the process of international development for the small and medium-sized enterprises gradually changes from pure national culture environment to cross culture environment, which cause the human resource management of small and medium enterprises face with some new problems in a certain extent, and it has a certain negative effects for the sustained and healthy development of enterprises under the cross culture background, therefore, it is very necessary to solve the problem of human resource management of small and medium enterprises in our country under the background of cross culture, and provides the appropriate protection for the sustained and healthy development for small and medium enterprises in the future .

\section{Definition of cross culture human resource management}

Cross culture human resource management is the human resources management implemented based on the cross culture background. Under the cross culture background, generally there will be certain culture background differences existing among employees in company, therefore, the requirements of employees about human resource management are not the same, culture element is inevitable to have comprehensive influence during the personal development of employees and the building process of enterprises. Therefore, in order to strengthen human resource management in small and medium enterprises under the current background of cross culture, companies must combine with the status quo of the corresponding culture background, implement targeted management of staff and promote the significantly improvement of management efficiency and effectiveness.

The development status of small and medium sized enterprises under the background of internationalization and cross culture human resource management issues

The development status of small and medium sized enterprises under the background of internationalization.

After our country joined the World Trade Organization, small and medium enterprises has also ushered in new development opportunities, and has shown the new development features in the new period $^{[1]}$. Facing with current globalized market competition and the influence of culture differences 
on their participation in the process of the international economic, the small and medium enterprises make appropriate adjustments for their development strategies based on the cross culture background, and further accelerate the pace of integration into the international market. But analyze from the perspective of cross culture, there are still some existed problems during the process of these enterprises' integration into the world economic system as affected by the impact of culture differences, and the most critical point is the human resources management of small and medium enterprises under the cross culture background.

\section{Analysis of the current problems of human resource management in small and medium sized enterprises from the perspective of cross culture.}

1) Multicultural conflict problem

Under multicultural background, there are differences in the working environment of employees in small and medium sized enterprises, which has a certain influence on the staff's thought, therefore, companies pay great attention to the national culture in the management of the enterprise and the relatively ignore foreign cultures, and companies tend to make a simple transplant and infiltration of national culture in the process of specific business management, which is extremely easy to cause the conflict between national culture and foreign culture, and it will have negative impact on smooth development of the work for expatriate managers . Meanwhile, analyzing the culture conflict from the cross culture perspective will inevitably lead to the conflict of enterprise management level, it is not conducive to the full play of the advantages of human resources. At the same time, there are certain culture background differences among different employees in the enterprise, it is very easy to have group interest conflict among these employees, which is not conducive to the optimization and adjustment of small and medium enterprises for their operating management activities.

2) Relatively low attraction for international talent

In the process of internationalization of small and medium enterprises, influenced by culture differences in different countries, enterprises must have the appropriate personnel to obtain a better development, and the compound talents with a certain cross culture ability is the pursuit goal of personnel training of enterprise human resources management ${ }^{[2]}$. But at present, affected by the characteristics of small and medium enterprises in our country , the attraction for cross culture talents from small and medium enterprises of this type is relatively low , in a certain extent, it increases the difficulty of talent recruitment and talent retention, and will play a certain adverse effects for the promotion of the international competitiveness of enterprises and the human resources management advantage.

3) International talent deployment problem

During the process of the development of international business ,the small and medium-sized enterprises in our country will also face issues of key positions and positions configuration combined with the different countries of the staff, Only in combination with the culture background and personal development needs of employees, arrange position for staff reasonably, build an efficient and cooperative team, can the small and medium-sized enterprises be able to get better international development. Small and medium sized enterprises should implement human resource management from the perspective of cross culture, promote the staff to fully play their personality advantages, so as to make corresponding contributions to the international competition of small and medium sized enterprises.

4) Cross cultural talent management problems based on different culture background

In the process of implementing internationalization management for small and medium sized enterprises, enterprises will also face the influences from different social culture, customs, value trends and so on, therefore in the process of small and medium enterprises going abroad for the world economic market, they must take some measures to deal with the impact of cultural differences. Based on this, enterprises should pay more attention to the analysis of cross-cultural communication, 
and coordinate the communication and understanding differences between different cultures to avoid contradiction and conflict arising from cultural differences utmost. 
5) Understanding and integration into the cultural construction of small and medium enterprises of global employees

Enterprise culture is the independent value concept formed under specific economic and social background and gradually get corresponding development, which is also the group consciousness of enterprise staff under the influence of the value concept, ethical standards and industry norms and so on. ${ }^{[3]}$ In the process of international competition, the management of enterprise culture of small and medium sized enterprises in our country should avoid a simple transplant for the company culture to prevent a violent conflict with host cultures, which will cause great adverse effects on enterprise staff cohesion.

6) Global implementation of barrier free communication for information of small and medium enterprises

Analysis from the perspective of cross culture, under the background of economic globalization, management of small and medium enterprises is also facing the problem of barrier free information communication globally. Therefore, in order to ensure that information is accessible without barriers, enterprises should also pay attention to the cultivation of cross cultural talents, cultivate cross cultural talents in enterprises through the implementation of scientific human resource management, create conditions for the advantage development of cross cultural talent and lay a solid foundation for the internationalization of small and medium-sized enterprises.

\section{Human resource management strategy of small and medium sized enterprises based on cross cultural analysis}

Under the background of economic globalization, in order to avoid a certain culture conflict within the enterprise in the process of internationalization management of small and medium sized enterprises in our country, enterprise management level should optimize and adjust the strategy of human resource management from the perspective of cross culture, and combine the differences between different cultures to implement strategies of culture localization, culture overlapping, culture compatibility, culture avoidance and culture fertilization, which can significantly promote the quality of human resource management in small and medium enterprises, meet the development needs of the current enterprise for their internationalization management, and make a contribution to the sustained and healthy development of enterprises

\section{Culture localization strategy.}

Generally, the small and medium-sized enterprises in our country will invest overseas during the process of the implementation of international operations, and they have to employ local staff to do this part of work. ${ }^{[4]}$ And small and medium-sized enterprises should start from the cross cultural background to manage this part of the staff , implement humane management of employees on the basis of fully understanding the local social culture, and further enhance employee's sense of identity, promote their consciousness and contribute to corresponding strength in the process of enterprise construction , ensure the human resources management function can be fully played, and provide corresponding human resources guarantee for the enterprise internationalization management development .

\section{Culture transplantation strategy.}

Culture transplantation strategy of the implementation of human resource management in the process of internationalization of small and medium sized enterprises from the perspective of cross culture belongs to rational use of the model of national center during the process of resource management. The core of the culture transplantation strategy is that during implementation of the internationalization management of the small and medium sized enterprises in the process of the development in other countries around the world, all the important management positions are appointed by native managers, In this situation, because there are no culture differences between managers and their own cultures, therefore there will be good information communication between the development of enterprises in other countries and the construction of domestic enterprises, and 
promote the cultural transplantation from home country to foreign lands during the actual development process of enterprises, let the employees of other countries gradually accept the parent culture and complete the tasks under the native cultural influence.

\section{Culture grafting strategy.}

The culture grafting strategy of the small and medium sized enterprises in the process of international operation and management belongs to the category of "multi center policy". The culture grafting strategy is to take the home country's corporate culture as the main culture of small and medium sized enterprises for their international management, and then develop appropriate human resource management practices combined with the social development status of the host country to further enhance the human resource management level. Seeing from aspect of the configuration of enterprise staff, it means the main management positions in the company of the home country are taken charge by the home country's managers, but will also employ part of managers from the host countries or business developing countries. The development advantage of this kind of human resources management strategy lies in that it can give consideration to multi-culture shocks of small and medium-sized enterprises in the globalization management process, and can implement flexible management of enterprise human resources. But there are certain drawbacks for the application of this strategy that means in a variety of cultural conflict, there will be certain difficulties for cross culture grafting between two cultures, rate of successful grafting is relatively low, therefore the small and medium-sized enterprises should comprehensively analyze enterprise human resources management and development needs in the process of international operation from the cross-cultural perspective, and then choose the appropriate management strategy to implement scientific management of the enterprise human resources .

\section{Culture compatibility strategy.}

Cultural compatibility strategy is also graphically called complementation of cultures in the process of practical application, which means that small and medium enterprises will not take the culture of home country or host country as the host culture of implementing human resource management of company in the process of international operation, but based on big differences between cultures of home country and host country and on the basis of fully understanding the culture of two countries, taking the common characteristics of the two countries as an entry point, make mutual supplement of cultures of two countries, and then give full play to the advantages of the two cultures, encourage small and medium-sized enterprises to get more competition in the world. In the process of application for compatible cultural policy, small and medium-sized enterprises should pay attention to the culture analysis of different countries from the angle of cross-culture, and then explore the complementarities among the different cultures based on the multiple cultural differences, and apply this complementarity in the process of the enterprise human resources management, so as to implement internationalization management for internal staff of enterprise in different countries. Only by doing this, can enterprises really develop the advantages of the compatible culture strategy, and make the right decisions for human resource management of small and medium enterprises from the angle of cross-cultural, which leads to the smoothly running for internationalization management of small and medium-sized enterprises.

\section{Culture aversion strategy.}

The application of culture aversion strategies in human resources management work of the small and medium-sized enterprise during the implementation of the international operation, means that when there is certain differences between home culture and the culture of business development countries for small and medium-sized enterprise, and the culture of the home country occupies the main position in the process of its human resource management for business development countries, but the enterprise must keep the corresponding focus on the culture of business development countries, then there will be managers dispatched from home country to manage the work of business development countries, during this process, managers should pay attention to make analysis of culture difference between the two countries from the cross-cultural perspective, and take the appropriate avoidance measures to avoid the cultural conflicts and the negative effects of enterprise 
human resources management work. Especially for some countries with strong national religious culture influence, managers of enterprises should respect the beliefs of local staff, try their best to avoid serious consequences caused by belief offending and the bad influence of the internationalized operation of small and medium-sized enterprises.

\section{Culture penetrating strategy.}

For international operation of small and medium-sized enterprises, which often requires long observation and cultivating stage for implementing corresponding human resource management based on the cultural penetration. The small and medium-sized enterprises send the corresponding managers to host country in the process of actual operation, analysis from the point view of cross culture, as there is inevitably big culture difference between home country and host country, therefore, if managers force employees of host country to accept their home country culture and human resource management mode in a short time, it will be inevitably to have a poor management effect, instead if managers make use of the cultural advantage formed by the strong economic power and cultural strength of home country, implement cultural infiltration for local staff gradually in the management process of host countries, let local employees to accept the influence of home country culture gradually during the working process, which will inevitably achieve good effect of human resource management and promote the better development of the small and medium-sized enterprises for their internationalization management.

\section{Conclusion}

In conclusion, under the background of economic globalization, if small and medium enterprises want to gain certain advantages in the international market competition, they should stand for a good viewpoint on the multicultural conflict under the background of economic globalization, analyze human resource management from the perspective of cross culture, put forward related human resource management measures, effectively enhance human resource management level in small and medium enterprises, cultivate cross cultural compound talents and at the same time ensure that each person's own advantages can be fully played, make related contribution to the construction and development of enterprises, and provide a solid guarantee for the good development of enterprises in the modern society.

\section{References}

[1] Cao Ying. Analysis of problems and countermeasures of human resource management in small and medium sized enterprises in China, Management observation, 2013(18):71-73.

[2] Liu Rong, Han Meiqing. The application of two factor theory in human resource management of small and medium sized enterprises, Jiangsu business theory, 2014 (1): 75-78.

[3] Xu Mei. Discussion on informatization development strategy of human resource management of small and medium sized enterprises in China, China commerce and trade, 2013 (24): 78-79.

[4] Du Wei, Li Huifang, Li Bing etc. The innovation research of human resource management of small and medium sized enterprises under the background of cloud economy, China commerce and trade. 2015(10):20-21,23.

[5] Zhang Bo. Exploration of human resources management of small and medium sized enterprises in China under the financial crisis, China commerce and trade. 2014(20):91-92. 